\title{
SISTEM AKUNTANSI PENGELOLAAN DANA DESA
}

\author{
Muhammad Ismail \\ Fakultas Ekonomi dan Bisnis,Universitas Sebelas Maret \\ ismail.akuntan@gmail.com \\ Ari Kuncara Widagdo \\ Fakultas Ekonomi dan Bisnis, Universitas Sebelas Maret \\ Widagdo2009@gmail.com \\ Agus Widodo \\ Fakultas Ekonomi dan Bisnis, Universitas Sebelas Maret \\ Awd_hatta@yahoo.com
}

\begin{abstract}
The aim of this study is to identify problems related to management of the village fund and to provide a guidance of village fund management. This study is conducted in Kismoyoso village and Giriroto Village in Ngemplak - Boyolali. This study used observation and interview method. The result showed that the main problem related to village fund is the lack of knowledge of the village head in implementing financial management of village fund based on Regulation No. 113/2015. It is coupled with a lack of facilitators from Boyolali district to assist the management of the village fund. This study purposed a computerized system for implementing the financial report is the solution to overcome these obstacles. By using this computerized system, reporting village fund will be done quickly and the financial statements will also be more reliable than reporting manually.
\end{abstract}

Keywords: Financial reporting, accounting information system, village fund

\begin{abstract}
ABSTRAK
Penelitian ini bertujuan mengidentifikasi permasalahan yang dialami desa terkait pengelolaan dana desa dan memberikan bimbingan pengelolaan dana desa. Penelitian dilakukan di Desa Kismoyoso dan Desa Giriroto Kecamatan Ngemplak Boyolali. Penelitian ini menggunakan metode observasi dan wawancara. Hasil penelitian menunjukkan bahwa permasalahan utama yang timbul adalah rendahnya pengetahuan dari kepala desa terkait pengelolaan keuangan desa berdasarkan Permendagri No. 113/2015. Hal itu ditambah lagi dengan belum adanya tenaga pendamping dari Kabupaten Boyolali untuk membantu pengelolaan dana desa. Penelitian ini mengusulkan sistem terkomputerisasi untuk pelaporan dana desa sebagai solusi. Dengan sistem yang berkomputerisasi, pelaporan dana desa akan mampu dilakukan dengan cepat dan output laporan keuangannnya juga akan lebih handal dibanding dengan pelaporan secara manual.
\end{abstract}

Kata kunci: Pelaporan keuangan, sistem informasi akuntansi, dana desa 


\section{PENDAHULUAN}

Undang-Undang Nomor 6 Tahun 2014 tentang desa menimbulkan polemik dan pro kontra dimasyarakat. Isu-isu tentang otonomi daerah, khususnya desa dan peraturan yang melingkupinya, merupakan isu yang menarik untuk diteliti (Utomo dan Wahyudi 2008). Dalam sejarah desa atau yang disebut dengan nama lain bahwa desa telah ada sebelum Negara Kesatuan Republik Indonesia (NKRI) terbentuk sampai dengan sekarang ini (UU 6/2014). Chamber (1987) dalam Eko (2014) menjelaskan bahwa negara berdiri mengikuti perkembangan desa atau tut wuri handayani. Sebelum negara monarki atau sekarang bergeser menjadi negara kesatuan yang mengintegrasikan berbagai wilayah itu ada, desa sudah ada lebih dulu. Oleh sebab itu, desa sudah sejak lahirnya merupakan wilayah yang bersifat otonom dan selalu akan dinamis (Susetiawan 2009).

Sejarah panjang pengaturan tentang desa yang telah dimulai sejak tahun 1948, yang momentumnya pada era reformasi dan puncaknya pada tahun 2014 Hoesada (2014), tidak lain dalam rangka untuk mencari bentuk dan format ideal yang bisa menempatkan posisi desa sebagai suatu daerah yang memiliki sifat istimewa, heterogen, kejelasan status serta kepastian hukumnya dalam sistem ketatanegaraan Republik Indonesia (Faozi 2015a). Regulasi atas pengelolaan desa mulai UndangUndang Nomor 22 Tahun 1948 tentang Pokok Pemerintahan Daerah, Undang-Undang Nomor 1 Tahun 1957 tentang Pokok-Pokok Pemerintahan Daerah, Undang-Undang Nomor 18 Tahun 1965 tentang Pokok-Pokok Pemerintahan Daerah, Undang-Undang Nomor 19 Tahun 1965 tentang Desa Praja, Undang-Undang Nomor 5 Tahun 1979 tentang Pemerintahan Desa, Undang-Undang Nomor 22 Tahun 1999 tentang Pemerintahan Daerah, dan terakhir dengan Undang-Undang Nomor 32 Tahun 2004 tentang Pemerintahan Daerah (Penjelasan UU 6/2014).

Berbagai peraturan tersebut tampaknya belum mampu mengembalikan pada eksistensi sejati desa sebagai level pemerintahan terendah yang memiliki hak mengatur rumah tangganya sendiri dengan tanpa meninggalkan adat istiadat (Risadi 2015). Pengaturan mengenai desa tersebut belum dapat mewadahi segala kepentingan dan kebutuhan masyarakat desa yang hingga saat ini sudah berjumlah sekitar 73.000 (tujuh puluh tiga ribu) desa dan sekitar 8.000 (delapan ribu) kelurahan (Penjelasan UU 6/2014).

Pelaksanaan pengaturan desa yang selama ini berlaku dianggap sudah tidak sesuai lagi dengan perkembangan zaman, terutama antara lain menyangkut kedudukan masyarakat hukum adat, demokratisasi, keberagaman, partisipasi masyarakat, serta kemajuan dan pemerataan pembangunan sehingga menimbulkan kesenjangan antar wilayah, kemiskinan, dan masalah sosial budaya yang dapat mengganggu keutuhan Negara Kesatuan Republik Indonesia. UU Nomor 6 Tahun 2014 lahir dalam rangka untuk menyempurnakannya. 
Lahirnya UU 6/2014 dianggap sangat fenomenal (Buton 2015), tonggak baru bagi sebuah negara dengan sistem pembangunan bottom-up yang sebelumnya pembangunan menganut sistem up-bottom (Azhar 2015) yang akan menjadikan kedudukan desa lebih diakui (Ismadani 2016), sekaligus memberikan payung hukum yang kuat terhadap eksistensi desa (Risadi 2015). Dengan UU 6/2014, desa akan memasuki babak baru untuk penataan dan pembangunan wilayahnya (Yansen 2014) yang datang membawa harapan-harapan baru bagi kehidupan kemasyarakatan dan pemerintahan yang ada di desa (Faozi 2015).

UU Nomor 6 Tahun 2014 mengangkat desa menjadi subjek kepemerintahan, yaitu dari sekedar objek pembangunan sekarang menjadi subjek pembangunan (Hoesada 2014). Desa tidak lagi sebatas menjadi objek pembangunan, namun desa bisa menjadi subyek untuk membangun kesejahteraan. Undang-undang tersebut menegaskan komitmen politik dan konstitusional bahwa negara melindungi dan memberdayakan desa agar menjadi kuat, maju, mandiri, dan demokratis sehingga dapat menciptakan landasan yang kokoh dalam melaksanakan pemerintahan dan pembangunan menuju masyarakat yang adil, makmur, dan sejahtera (Eko 2014a).

Lebih jauh, Muqowam dalam Eko (2014a) mengemukakan bahwa UU Desa ini hendak membuat desa bertenaga secara sosial, berdaulat secara politik, berdaya secara ekonomi, dan bermartabat secara budaya, yang dikenal sebagai Catur Sakti Desa. Fauzi dalam Eko (2014b) juga menjelaskan undang-undang desa ini diharapkan dapat menjawab berbagai permasalahan di desa yang meliputi aspek sosial, budaya, ekonomi, serta memulihkan basis penghidupan masyarakat desa dan memperkuat desa sebagai entitas masyarakat yang kuat dan mandiri. Desa juga diharapkan dapat menjalankan mandat dan penugasan beberapa urusan yang diberikan oleh pemerintah provinsi, dan terutama pemerintah kabupaten/kota yang berada diatasnya, serta menjadi ujung tombak dalam setiap pelaksanan pembangunan dan kemasyarakatan. Akibatnya, pengaturan desa juga dimaksudkan untuk mempersiapkan desa dalam merespon proses modernisasi, globalisasi dan demoktratisasi yang terus berkembang tanpa kehilangan jati dirinya.

Undang-undang (UU) desa ini diharapkan akan mengangkat desa pada posisi subjek yang terhormat dalam kehidupan berbangsa dan bernegara, karena akan menentukan format desa yang tepat sesuai dengan konteks keragaman lokal, serta merupakan instrument untuk membangun visi menuju kehidupan baru desa yang mandiri, demokratis dan sejahtera. UU desa ini memberikan kesempatan bagi desa dan senjata bagi rakyat desa untuk melancarkan perubahan. Desa akan layak sebagai tempat kehidupan dan penghidupan, menjadi fondasi penting bagi kemajuan bangsa dan negara dimasa yang akan datang.

Kelahiran UU Nomor 6 Tahun 2014 dirasa pada saat yang tepat, maka tidak aneh kalau kemudian disambut luar biasa oleh masyarakat, ada semangat baru yang hidup dan ada new files yang akan segera hadir di desa Karim dalam (Eko 2014a). Jika 
UU ini diterapkan sungguh-sungguh sesuai tujuan oleh semua pihak akan mampu menciptakan perubahan yang signifikan terhadap kemajuan dan kesejahteraan di desa.

Pembangunan sarana prasarana desa dan dusun pada tahun-tahun yang akan datang akan meningkat secara signifikan, aparat desa akan mendapat gaji dari negara (Hoesada 2014). Desa akan segera mendapatkan dana miliaran rupiah. Alokasi Anggaran Pendapatan dan Belanja Negara untuk desa akan selalu meningkat dari tahun ke tahun (Brodjonegoro 2014). Desa akan mempunyai sumber pendapatan berupa Pendapatan Asli Desa, Bagi Hasil Pajak Daerah dan Retribusi Daerah Kabupaten/Kota, bagian dari Dana Perimbangan Keuangan Pusat dan Daerah yang diterima oleh Kabupaten/Kota, alokasi anggaran dari APBN, bantuan keuangan dari APBD Provinsi dan APBD Kabupaten/Kota, serta hibah dan sumbangan yang tidak mengikat dari pihak ketiga (PP No. 60 Tahun 2014).

Anggaran Pendapatan dan Belanja Desa diperkirakan besarnya cukup fantastis dan bervariasi karena nilainya mendekati angka satu milyar rupiah per desa bahkan bisa lebih bervariasi sesuai dengan kondisi desa. Nilainya akan berlipat jika dibandingkan dengan dana Alokasi Dana Desa (ADD) yang selama ini diterima oleh desa yang hanya berkisar di angka puluhan sampai dengan ratusan juta rupiah. Adanya tambahan dana tersebut diharapkan pemerintah desa akan semakin mampu dalam membangun serta memberdayakan masyarakat desa (Faozi 2015).

Namun demikian, tidak sedikit kalangan yang khawatir dengan lahirnya undang-undang ini. Lahirnya UU 6/2014 dianggap sebagai kebijakan politis semata yang justru akan menjerat para aparat desa (Wiyanto 2014). Banyak pihak menganggap kemampuan para aparat desa di daerah yang masih rendah dan belum siap tersebut justru dikhawatirkan akan membawanya pada meja hijau. Dalam hal pengelolaan dana desa, akan ada risiko terjadinya kesalahan baik bersifat administratif maupun substantif yang dapat mengakibatkan terjadinya permasalahan hukum mengingat belum memadainya kompetensi kepala desa dan aparat desa dalam hal penatausahaan, pelaporan, dan pertanggungjawaban keuangan desa (BPKP 2015). Hal itu terjadi karena pemerintahan desa yang akan mendapatkan pendanaan program dan kegiatan dari berbagai sumber (APBN dan APBD Provinsi/Kabupaten) mengandung konsekuensi harus mampu mengelola secara transparan, akuntabel, dan bebas dari penyalahgunaan.

Kondisi aparatur pemerintah daerah saat ini kemampuannya masih rendah, terutama dalam hal pengelolaan keuangan daerah (Sidik 2002). Pada tataran pertanggungjawaban pengelolaan administrasi keuangan, kompetensi sumber daya manusia di desa merupakan kendala utama (Subroto 2009). Kapasitas sumber daya manusia di desa selama ini kurang merata (Yuliana 2013). Kementerian keuangan juga menilai perangkat desa masih belum siap untuk menerima anggaran dana desa saat ini (Basri 2014). Terdapat masalah kapasitas administrasi dan tata kelola aparat pemerintah desa yang masih minim. Sistem akuntabilitas dan pranata pengawasan 
yang masih lemah, termasuk belum kritisnya masyarakat atas pengelolaan anggaran pendapatan dan belanja desa. Badan Perwakilan Daerah (BPD) yang merupakan manivestasi perwakilan atau DPR-nya desa di berbagai daerah masih mengalami stagnanisasi lembaga, yaitu hanya menjadi lembaga formalitas tanpa memiliki progres yang menggembirakan (Azhar 2015).

Berangkat dari kasus pro kontra dan kekhawatiran terhadap UU 6/2014 ini, maka peneliti menganggap perlu ada sebuah penelitian lebih lanjut yang dapat memberi solusi terhadap permasalahan yang ada. Hal ini diharapkan dapat mengurangi kekhawatiran banyak pihak, yaitu ada para aparat desa yang berurusan dengan penegak hukum karena ketidaktahuan dan ketidakmampuannya dalam mengelola dana desa.

Pertanyaan penelitian ini adalah: (1) bagaimana kesiapan aparat desa terkait dengan pelaksanaan Undang-Undang 6/2014? (2) apakah benar bahwa aparat desa lemah dalam hal penatausahaan keuangan dana desa? (3) apakah benar bahwa aparat desa tidak mempunyai kemampuan membuat laporan keuangan seperti yang diamanahkan UU 6/2014 dan Permendagri 113/2014 tentang Pengelolaan Keuangan Desa? Penelitian ini diharapkan dapat memberikan input pada pemerintah pusat tentang kesiapan desa untuk mengimplementasikan UU 6/2014 dalam hal pengelolaan dana desa dan memberikan pemahaman kepada aparat desa tentang sistem akuntansi terkait pengelolaan dana desa. Penelitian ini mengharapkan aparat desa mampu melakukan pengelolaan dana desa mulai dari pencatatan sampai pelaporan secara reliabel, dan tepat waktu.

\section{KAJIAN PUSTAKA}

\section{Pengertian Evaluasi}

Suatu kebijakan baik yang dibuat dan dirumuskan secara baik, belum tentu dapat diimplementasikan sesuai rencana. Beberapa institusi atau lembaga kadang justru tidak dapat melaksanakan kebijakan tersebut, sehingga perlu adanya evaluasi supaya dapat memberikan penilaian baik itu berupa usulan, kritik dan saran terhadap kebijakan yang dibuat mulai dari implementasi sampai dengan dampak hasil kebijakan yang terjadi. Wrightstone (1956) mengemukakan evaluasi adalah penaksiran terhadap pertumbuhan dan kemajuan ke arah tujuan atau nilai-nilai yang telah ditetapkan. Secara umum, evaluasi adalah suatu proses untuk menyediakan informasi tentang sejauh mana suatu kegiatan tertentu telah dicapai, bagaimana perbedaan pencapaian dengan perencanaan sehingga bisa diketahui apakah ada selisih di antara keduanya, serta bagaimana manfaat yang telah dikerjakan itu bila dibandingkan dengan harapan-harapan yang ingin diperoleh. Tujuan akhir dari evaluasi adalah untuk memberikan masukan bagi proses kebijakan ke depan agar dihasilkan kebijakan yang lebih baik. Pada dasarnya, evaluasi kebijakan memang dimaksudkan untuk melihat keberhasilan atau tingkat pencapaian suatu kebijakan yang telah diimplementasikan terhadap kelompok sasaran yang dikenai kebijakan tersebut. 


\section{Otonomi Daerah}

Undang-Undang Republik Indonesia Nomor 32 Tahun 2004 tentang Pemerintahan Daerah menjelaskan bahwa yang dimaksud pemerintahan daerah adalah penyelenggaraan urusan pemerintahan oleh pemerintah daerah dan DPRD menurut asas otonomi dan tugas pembantuan dengan prinsip otonomi seluas-luasnya dalam sistem dan prinsip Negara Kesatuan Republik Indonesia sebagaimana dimaksud dalam Undang-Undang Dasar Negara Republik Indonesia Tahun 1945. Undang-Undang Republik Indonesia Nomor 6 Tahun 2014 tentang desa menjelaskan yang dimaksud dengan desa adalah desa dan desa adat atau yang disebut dengan nama lain, selanjutnya disebut desa, adalah kesatuan masyarakat hukum yang memiliki batas wilayah yang berwenang untuk mengatur dan mengurus urusan pemerintahan, kepentingan masyarakat setempat berdasarkan prakarsa masyarakat, hak asal usul, dan/atau hak tradisional yang diakui dan dihormati dalam sistem pemerintahan Negara Kesatuan Republik Indonesia. Pemerintahan desa adalah penyelenggaraan urusan pemerintahan dan kepentingan masyarakat setempat dalam sistem pemerintahan Negara Kesatuan Republik Indonesia. Pemerintah desa adalah kepala desa atau yang disebut dengan nama lain dibantu perangkat desa sebagai unsur penyelenggara pemerintahan desa.

\section{Teori Agensi dan Akuntabilitas}

Teori agensi merupakan konsep yang menjelaskan hubungan kontraktual antara principals dan agents. Pihak principals adalah pihak yang memberikan mandat kepada pihak lain, yaitu agent, untuk melakukan semua kegiatan atas nama principals dalam kapasitasnya sebagai pengambil keputusan (Jensen dan Smith 1984). Pada pemerintahan daerah di Indonesia secara sadar atau tidak, teori agensi sebenarnya telah dipraktikkan. Pada organisasi sektor publik yang dimaksud principal adalah rakyat dan agen adalah pemerintah dalam hal ini adalah kepala desa dan aparat desa lainnya. Peraturan Pemerintah Republik Indonesia Nomor 71 Tahun 2010 tentang Standar Akuntansi Pemerintahan memberikan penjelasan tentang adanya hubungan yang jelas antara teori agensi dengan akuntabilitas.

Akuntabilitas adalah kewajiban pemegang amanah/agent/kepala desa dan aparatnya untuk memberikan pertanggungjawaban, menyajikan, melaporkan, dan mengungkapkan segala aktivitas dan kegiatan yang menjadi tanggung jawabnya kepada pihak pemberi amanah (principal) yang memiliki hak dan kewenangan untuk meminta pertanggungjawaban tersebut. Secara singkat, kepala desa dan aparaturnya harus mempertanggungjawabkan pengelolaan sumber daya serta pelaksanaan kebijakan yang dipercayakan kepada entitas pelaporan dalam mencapai tujuan yang telah ditetapkan secara periodik. Transparansi memberikan informasi keuangan yang terbuka dan jujur kepada masyarakat berdasarkan pertimbangan bahwa masyarakat memiliki hak untuk mengetahui secara terbuka dan menyeluruh atas pertanggungjawaban pemerintah dalam pengelolaan sumber daya yang dipercayakan kepadanya dan ketaatannya pada peraturan perundang-undangan. 


\section{Pengertian Akuntansi dan Sistem Akuntansi}

Menurut Peraturan Pemerintah Republik Indonesia Nomor 71 Tahun 2010 tentang Standar Akuntansi Pemerintahan, akuntansi adalah proses identifikasi, pencatatan, pengukuran, pengklasifikasian, pengikhtisaran transaksi dan kejadian keuangan, penyajian laporan, serta penginterpretasian atas hasilnya. Halim dan Kusufi (2012) menjelaskan yang dimaksud akuntansi keuangan daerah adalah proses pengidentifikasian, pengukuran, pencatatan, dan pelaporan transaksi ekonomi (keuangan) dari entitas pemerintah daerah (kabupaten, kota, atau provinsi) yang dijadikan sebagai informasi dalam rangka pengambilan keputusan ekonomi oleh pihak-pihak eksternal entitas pemerintah daerah yang memerlukan.

Menurut Halim dan Kusufi (2012), tujuan pokok akuntansi pemerintahan adalah: a) Pertanggungjawaban, yaitu memberikan informasi keuangan yang lengkap pada waktu yang tepat, yang berguna bagi pihak yang bertanggung jawab yang berkaitan dengan operasi unit-unit pemerintahan. Fungsi pertanggungjawaban mengandung arti yang lebih luas daripada sekedar ketaatan terhadap peraturan, tetapi juga keharusan bertindak bijaksana dalam penggunaan sumber-sumber daya. b) Manajerial, yaitu akuntansi pemerintahan juga harus menyediakan informasi keuangan untuk perencanaan, penganggaran, pelaksanaan, pemantauan, pengendalian anggaran, perumusan kebijaksanaan dan pengambilan keputusan serta penilaian kinerja pemerintah. Tujuan ini perlu dikembangkan agar organisasi pemerintah tingkat atas dan menengah dapat menjadikan informasi keuangan atas pelaksanaan yang lalu untuk membuat keputusan ataupun penyusunan perencanaan untuk masa yang akan datang, c) Pengawasan, yaitu akuntansi pemerintahan juga harus memungkinkan terselenggaranya pemeriksaan oleh aparat pengawasan fungsional secara efektif dan efisien.

Sistem akuntansi yang dirancang dan dijalankan secara baik akan menjamin dilakukannya prinsip stewardship dan accountability dengan baik pula. Pemerintah atau unit kerja pemerintah perlu memiliki sistem akuntansi yang tidak hanya berfungsi sebagai alat pengendalian transaksi keuangan, akan tetapi sistem akuntansi tersebut hendaknya mendukung pencapaian tujuan organisasi. Menurut Mulyadi (2001), sistem akuntansi adalah organisasi formulir, catatan, dan laporan yang dikoordinasi sedemikian rupa untuk menyediakan informasi keuangan yang dibutuhkan oleh manajemen guna memudahkan pengelolaan perusahaan. Formulir atau dokumen merupakan dokumen yang digunakan untuk merekam terjadinya transaksi. Peraturan Pemerintah Republik Indonesia Nomor 24 Tahun 2005 menjelaskan sistem akuntansi pemerintahan adalah serangkaian prosedur manual maupun yang terkomputerisasi mulai dari pengumpulan data, pencatatan, pengikhtisaran dan pelaporan posisi keuangan dan operasi keuangan pemerintah.

Berbagai penelitian telah dilakukan oleh para peneliti terdahulu terkait kualitas pelaporan keuangan sektor publik di Indonesia. Misalnya, Harun (2002) menyatakan 
tentang pentingnya peningkatan kualitas akuntansi sektor publik di Indonesia. Organisasi pemerintah, seperti layaknya perusahaan swasta besar, memerlukan informasi keuangan yang tepat waktu dan akurat untuk tujuan organisasi. Akbar (2011) menyimpulkan akuntabilitas publik dan keterbukaan merupakan dua sisi koin yang tidak terpisahkan sebagai bagian dari prinsip-prinsip tata pemerintahan yang baik (good governance). Sistem akuntansi pemerintahan memberikan peluang terhadap peningkatan penyediaan informasi yang handal dan akurat serta berorientasi pada peningkatan tolok ukur kinerja dalam memberikan pelayanan publik yang maksimal, dan merupakan proses pertanggungjawaban (stewardship and accountability process). Tanjung (2000) juga menyatakan bahwa laporan keuangan pemerintah daerah yang dihasilkan melalui proses akuntansi merupakan bentuk transparansi dan akuntabilitas pengelolaan keuangan publik.

Beberapa peneliti terdahulu menyatakan pentingnya pengaruh sistem akuntansi terhadap kualitas pelaporan keuangan pada sektor publik. Sadjiarto (2000) menyatakan bahwa good governance dan akuntabilitas pemerintahan di Indonesia sangat ditentukan dari pengelolaan keuangannya. Yahya (2006) juga memberikan kesimpulan yang seirama bahwa sistem akuntansi keuangan dan laporan keuangan pemerintah daerah adalah sarana akuntabilitas dan transparansi keuangan daerah. Kualitas pemerintahan daerah yang baik (good governance) sangat ditentukan oleh akuntabilitas, transparansi pengelolaan keuangannya. Furqani (2010) menyimpulkan ada korelasi positif antara pengelolaan keuangan yang baik dengan upaya untuk mewujudkan good governance. Demikian juga, penelitian Rusli (2004) memberikan data bahwa akuntansi keuangan sektor publik berpengaruh terhadap transparansi sebesar 10,8\%; dan akuntabilitas sebesar 66,8\%. Yuliani et al. (2010) menyatakan bahwa pemahaman akuntansi berpengaruh terhadap kualitas laporan keuangan pemerintah kota. Aliyah dan Nahar (2012) menyatakan bahwa penyajian laporan keuangan daerah berpengaruh positif dan signifikan terhadap transparansi dan akuntabilitas pengelolaan keuangan daerah. Penyajian laporan keuangan daerah secara lengkap yang sesuai dengan standar akuntansi pemerintahan dan mudah diakses oleh semua pihak yang berkepentingan memungkinkan kontrol dan pengawasan terhadap pengelolaan keuangan bisa berjalan dengan baik.

Hal lain yang mempengaruhi kualitas pelaporan keuangan sektor publik adalah kualitas sumber daya manusia. Dengan kata lain, rendahnya pemahaman tentang akuntansi berpengaruh terhadap pembuatan laporan keuangan serta transparansi dan akuntabilitas pengelolaan keuangan daerah. Namun, sayang sesuatu yang sangat mendasar dan harus dimiliki aparat pemerintah daerah tersebut justru sampai saat ini belum menunjukkan tanda-tanda yang menggemberikan. Banyak penelitian membuktikan bahwa masih rendahnya SDM pemerintah daerah dalam melakukan pengelolaan dan pelaporan keuangan. Misalnya, Sidik (2002) menyindir tentang masih rendahnya kondisi aparatur pemerintah daerah saat ini, terutama dalam hal pengelolaan keuangan daerah. Sementara, penelitian Subroto (2009) mengungkapkan 
bahwa secara umum desa dalam memberikan pertanggungjawaban ADD sudah baik secara teknis, namun dalam hal pertanggungjawaban administrasi keuangan kompetensi sumber daya manusia pengelola merupakan kendala utama.

Kualitas pelaporan keuangan sektor publik di Indonesia masih mengalami berbagai kendala. Belum baiknya sistem akuntansi yang diterapkan dan rendahnya pemahaman terhadap akuntansi merupakan beberapa kendala yang dihadapi sektor publik di Indonesia. Masalah tersebut terjadi baik di level pemerintah pusat maupun pemerintah daerah.

\section{METODA PENELITIAN}

\section{Data Penelitian}

Penelitian ini merupakan penelitian kualitatif dengan studi kasus. Lokasi penelitian ini adalah dua desa di Kecamatan Ngemplak Kabupaten Boyolali, yaitu Desa Giriroto dan Desa Kismoyoso. Pemilihan lokasi pada kedua desa tersebut dengan pertimbangan kedua wilayah ini karena proses pencairan dana desa sudah terjadi dan programnya sudah dalam tahap pelaksanaan. Penelitian ini melakukan observasi dengan peninjauan langsung pada kedua desa untuk mendapatkan gambaran nyata mengenai kesiapan dan penatausahaan keuangan yang sedang berjalan pada kedua desa untuk memperoleh gambaran tentang kesiapan dan proses serta format pelaporan dana desa. Wawancara dilakukan dengan cara bertanya langsung dengan nara sumber mulai dari kepala desa, bendahara, badan perwakilan desa dan masyarakat terkait pengelolaan dana desa termasuk juga pelaporannya.

\section{ANALISIS DAN PEMBAHASAN}

\section{Hasil Wawancara}

Wawancara telah dilakukan dengan berbagai pihak di Desa Kismoyoso dan Desa Giriroto yang menjadi lokasi penelitian. Dari hasil wawancara dan observasi awal diperoleh beberapa temuan. Para kepala desa dan aparat pemerintah desa belum begitu paham dan siap dengan pelaksanaan UU 6/2014. Hal itu justru menimbulkan kecemasan dan kekhawatiran mereka. Kekurangsiapan dan kecemasan itu disebabkan karena minimnya sosialisasi dan bimbingan dari pemerintah Kabupaten Boyolali. Seluruh kepala desa dan aparatnya kalau disuruh memilih maka proses pencairan dana desa sebaiknya ditunda tahun depan, yaitu 2016.

Para kepala desa menyadari bahwa pengucuran dana desa yang bersumber dari APBN ini menuntut pertanggungjawaban dari setiap pemakaian rupiahnya. Permendagri No. 113 mengatur secara detail proses pelaporannya. Dalam Permendagri ini ini diatur nomor rekening, proses pencatatan, dan format pelaporan dana desa. Di sisi lain, para kepala desa dan aparatnya belum memiliki pemahaman 
yang memadai terhadap peraturan tersebut. Mereka mengeluhkan detailnya pencatatan dan pelaporan dana desa ini. Hal itu diperparah lagi dengan minimnya sumber daya manusia pada level desa. Hampir sebagian besar aparat di level desa sudah berusia tua, dan hanya sedikit pegawai desa yang berusia muda dan mungkin bisa diminta mempelajari Permendagri tersebut.

Hal-hal tersebut menimbulkan ketakutan diantara para kepala desa untuk membelanjakan dana desa. Para kepala desa lebih memilih mendapatkan bantuan dengan pola blockgrant dibandingkan dengan dana desa. Mereka berpendapat bahwa proses pertanggungjawaban bantuan dengan pola blockgrant relatif lebih sederhana dibanding dengan dana desa. Namun demikian, meskipun pelaporan pertanggungjawaban dana desa menimbulkan ketakutan pada kepala desa, mereka tetap berusaha mensukseskan pelaksanaan program dana desa dari pemerintah. Para kepala desa membuat program yang lebih banyak bersifat fisik untuk menyerap alokasi dana desa 2015. Mereka beranggapan bahwa program-program fisik tersebut relatif lebih sederhana dan jelas pertanggungjawabannya dibanding dengan program nonfisik. Hal ini mereka anggap sebagai jalan tengah, dana desanya terserap dan para kepala desa juga lebih mudah dalam pembuatan pertanggungjawabannya. Tentunya, program-program fisik ini sudah mereka musyawarahkan dulu di antara kepala desa, tim pengelola dana desa dan perwakilan masyarakat.

Hasil wawancara menunjukkan adanya berbagai permasalahan yang ada dilevel desa terkait implementasi dana desa. Secara umum, permasalahan yang berhasil didentifikasi peneliti tidak jauh berbeda dengan permasalahan-permasalahan yang sudah dikemukakan sebelumnya oleh para akademisi/birokrat, misalnya rendahnya kualitas sumber daya manusia di level desa, dan rendahnya pemahaman mereka terkait akuntansi dana desa. Tetapi, penelitian ini menemukan satu hal yang menarik, yaitu semangat aparatur pemerintah desa untuk tetap melaksanakan program dana desa yang merupakan program pemerintah pusat. Mereka tetap berusaha membuat program meskipun semuanya masih program fisik untuk menyerap dana desa yang dialokasikan ke desa. Hal ini menunjukkan adanya semangat untuk tetap mensukseskan program nasional pemerintah. Hal itu menunjukkan masih adanya kearifan lokal di level desa dalam menghadapi tantangan dalam implementasi dana desa.

\section{Sistem Akuntansi Keuangan Pengelolaan Dana Desa}

Dari data hasil wawancara dan observasi pendahuluan tentang ketidaksiapan kepala desa dan aparatnya yang lebih disebabkan karena masalah teknis, misalnya minimnya sosialisasi, bimbingan dan rendahnya kemampuan dibidang penatausahaan keuangan serta pelaporannya. Wawancara lanjutan dilakukan untuk mendapatkan data mengenai keinginan dan harapan kepala desa dan aparatnya pada proses implementasi UU 6/2014. Dari hasil wawancara dan observasi lanjutan didapatkan bahwa kepala 
desa dan aparatnya menginginkan suatu terobosan untuk memudahkan pengelolaan, penatausaahaan dana desa beserta pelaporannya.

Sistem akuntansi yang terkomputerisasi untuk melakukan pengelolaan dana desa sangat tepat mengingat juga dasar pendidikan kepala desa dan aparatnya bukan bidang akuntansi. Penyimpanan data pengelolaan keuangan tidak membutuhkan banyak berkas dan data tersimpan bisa digunakan dalam jangka waktu yang relatif lama. Selain komputer merupakan alat pengolah data yang tepat dengan akses ketelitian maupun kecepatan tinggi, sistem komputerisasi juga akan menghemat waktu dan bekerja dengan tingkat akurasi yang lebih dibandingkan dengan sistem manual.

Beberapa peneliti terdahulu menemukan berbagai manfaat dari penerapan komputerisasi sistem akuntansi pada sektor publik. Misalnya, Ratih (2012) menyatakan bahwa rancang bangun dan pemahaman sistem akuntansi keuangan daerah menjadikan sebuah proses menjadi mudah dan cepat serta kemampuan penatausahaan keuangan daerah dan pengelolaan barang milik daerah berpengaruh secara simultan terhadap kinerja SKPD. Sudana (2007) menyatakan bahwa sistem informasi akuntansi merupakan suatu sistem aplikasi terkomputerisasi yang mampu melakukan pengolahan data transaksi keuangan perusahaan secara terintegrasi. Rusmayanti et al. (2008) menyatakan bahwa adanya sistem pengelolaan keuangan di Desa, Kaur Keuangan menjadi lebih terbantu. Penyimpanan data pengelolaan keuangan tidak membutuhkan berkas banyak dan data bisa digunakan dalam jangka waktu yang relatif lama.

Sementara itu, penelitian Papuas (2012) menyatakan suatu lembaga atau organisasi yang menggunakan komputer untuk mengolah sistem informasinya, akan mempunyai nilai lebih dari pada sistem informasi yang diolah secara manual. Komputer merupakan alat pengolah data yang tepat dengan akses ketelitian maupun kecepatan tinggi dibandingkan akses kerja manusia. Helmy (2012) menyatakan sistem memberikan kemudahan dan kecepatan aparat bekerja dalam menyelesaikan tugastugasnya. Gustiawan (2013) berpendapat bahwa pengelolaan dan penggunaan data base dengan sistem komputerisasi akan menghemat waktu dan bekerja dengan tingkat akurasi yang lebih dibandingkan dengan sistem manual. Demikian juga, Sarwoko (2011) berpendapat suatu lembaga atau organisasi yang menggunakan komputer untuk mengolah sistem informasinya, akan mempunyai nilai lebih dari pada sistem informasi yang diolah secara manual dan komputer yang merupakan alat pengolah data yang tepat dengan akses ketelitian maupun kecepatan tinggi dibandingkan akses kerja manusia.

\section{Sistem Akuntansi Dana Desa Terkomputerisasi}

Berdasarkan data hasil wawancara, observasi lanjutan dan literatur review pada undang-undang desa 6/2014 dan Permendagri 113/2014, penelitian ini merancang sistem akuntansi dana desa berbasis komputer dan berhasil membuat sebuah program pengelolaan dana desa. Program ini kemudian diterapkan pada Desa Kismoyoso dan 
Desa Giriroto. Dalam penelitian ini juga melakukan pelatihan kepada para aparat desa terkait penerapan program komputer aplikasi dana desa tersebut.

Program aplikasi dana desa ini merupakan program yang berbasis microsoft acces. Sistem komputerisasi tersebut akan menghasilkan pengelolaan dan laporanlaporan sesuai dengan petunjuk yang ada di Permendagri 113/2014, dapat dilihat pada Tabel 1.

Tabel 1

Pengelolaan dan laporan program aplikasi dana desa

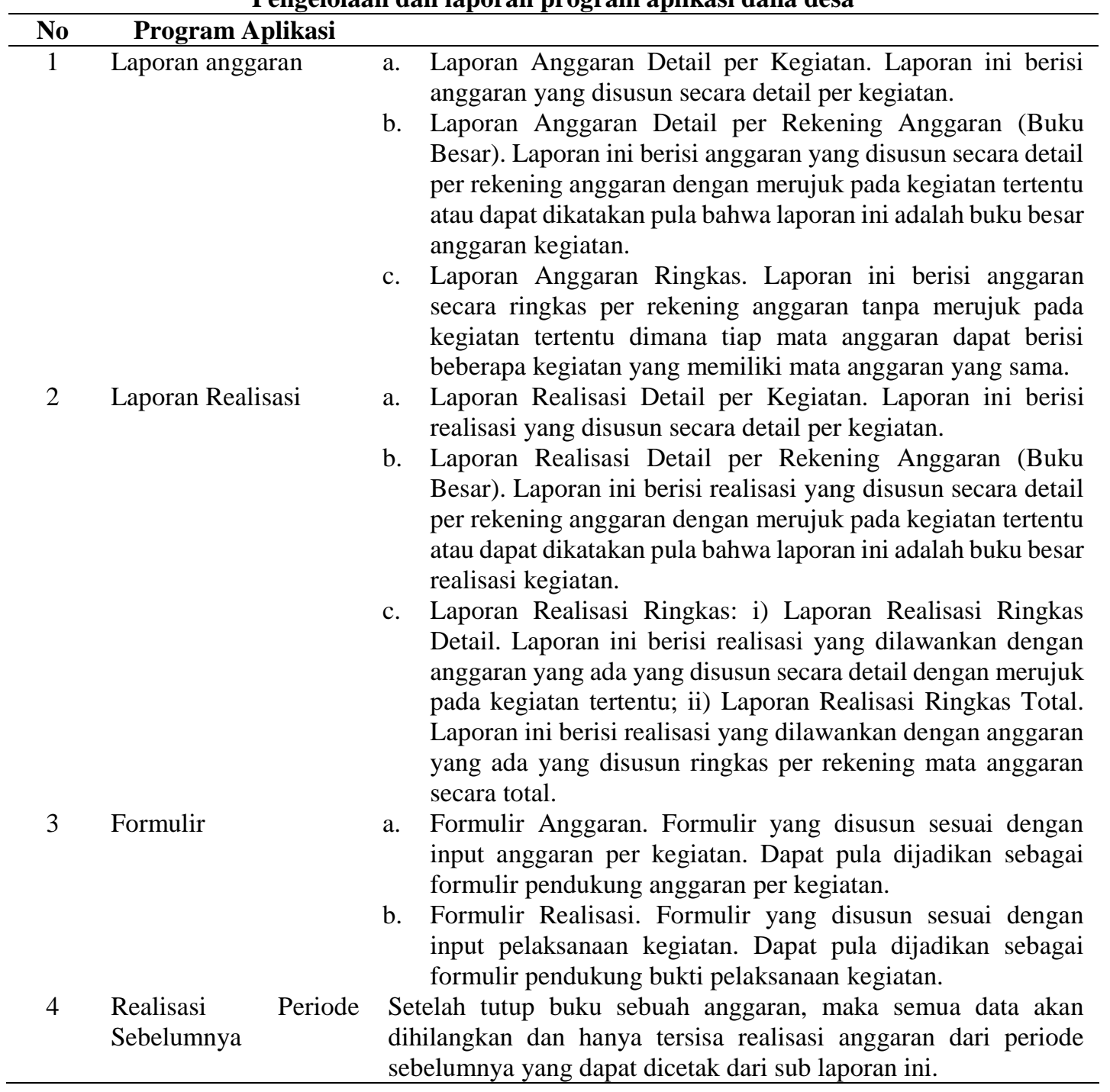




\section{SIMPULAN, KETERBATASAN DAN SARAN}

\section{Simpulan}

Berdasarkan hasil penelitian pada kedua desa diketahui bahwa para aparat desa memang belum memiliki kesiapan dalam pelaksanaan Undang-Undang 6/2014. Mereka belum memahami sepenuhnya pengelolaan dana desa berdasarkan Permendagri 113/2014. Hal ini diperparah lagi dengan rendahnya kualitas sumber daya manusia, minimnya sosialisai dan bimbingan. Meskipun demikian, para aparat desa memiliki semangat untuk tetap mensukseskan pelaksanaan program dana desa dari pemerintah pusat, yaitu dengan memperbanyak program fisik untuk menyerap dana desa.

Penerapan program sistem akuntansi pengelolaan dana desa yang terkomputerisasi dapat mengatasi permasalahan terkait pengelolaan dana desa. Sistem komputerisai ini akan memberi kemudahan kepada aparat desa mulai dari perencanaan, pencatatan secara akuntansi sampai membuat laporan keuangan semesteran dan tahunan. Hal ini bisa meningkatkan akuntabilitas publik, partisipasi masyarakat dan transparansi pengelolaan dana desa. Penggunaan sistem komputerisasi juga akan menghemat waktu kepala desa dan aparat desa, sehingga bisa melakukan tugas utamanya, yaitu memberikan pelayanan kepada masyarakat dan juga berbagai tugas sosial lainnya, misalnya menghadiri dan memberi sambutan kematian, hajatan, penyelesaian konflik yang ada dimasyarakat.

\section{Keterbatasan dan Saran}

Waktu penelitian ini pada bulan Agustus-September, ketika secara aturan proses pencairan dana desa baru tahap II dan belum bisa sampai tahap III. Akibatnya, penelitian ini belum mendapatkan gambaran secara lengkap dari program dana desa mulai dari proses perencanaan sampai dengan pelaporannya. Penelitian selanjutnya sebaiknya melakukan observasi dengan waktu yang lebih panjang yang meliputi semua aspek tahapan kegiatan pelaksanaan dana desa.

Saat ini, BPKP telah melakukan kerja sama dengan Depdagri terkait penerapan aplikasi pengelolaan dana desa. Hal ini tentunya merupakan sebuah langkah maju yang akan mempermudah aparat desa dalam mengelola dana desa. Oleh karena itu, sistem pengelolaan dana desa terkomputerisasi yang diajukan dalam penelitian ini bisa menjadi sistem antara sebelum benar-benar dilakukan migrasi ke aplikasi milik BPKP.

\section{DAFTAR PUSTAKA}

Akbar, B. 2011. "Akuntabilitas publik dan peran akuntansi keuangan daerah pada pemerintah daerah.” Pekik Daerah. 2011.

Aliyah, Siti, dan Aida Nahar. 2012. "Pengaruh penyajian laporan keuangan daerah dan aksesibilitas laporan keuangan daerah terhadap transparansi dan akuntabilitas pengelolaan keuangan daerah kabupaten Jepara." Jurnal Akuntansi \& Auditing 8 (2): 97-189. 
Azhar, Andi. 2015. "Euphoria undang-undang desa: peluang atau ancaman?" Kompasiana. 2015.

Basri, C. 2014. "Desa belum siap kelola dana desa yang besar.” Kementrian Keuangan. 2014.

Brodjonegoro, B.P.S. 2014. "Pemerintah tambah alokasi dana desa dalam APBN-P 2015.” Kementrian Keuangan. 2014.

Buton, Rauda Aspal. 2015. "Telaah kritis sisi probabilitas negatif undang-undang nomor 6 tahun 2014 tentang desa." Kompasiana. 2015.

Eko, Sutoro. 2014a. Desa membangun Indonesia. Yogyakarta: Forum Pengembangan Pembaharuan Desa (FPPD).

—. 2014b. Kedudukan dan kewenangan desa. Yogyakarta: Forum Pengembangan Pembaharuan Desa (FPPD).

Faozi, C. 2015a. "Harap-harap cemas undang-undang desa.” Kompasiana. 2015.

— 2015b. "Undang-undang desa, apakah mimpi buruk bagi aparatur pemerintah desa?” Kompasiana. 2015.

Furqani, Astri. 2010. "Pengelolaan keuangan desa dalam mewujudkan good governance (studi pada pemerintahan Desa Kalimo'ok Kecamatan Kalianget Kabupaten Sumenep)." UPN Jawa Timur.

Gustiawan. 2013. "Pengolahan data kependudukan: Menghasilkan laporan data penduduk, masuk, meninggal, lahir, pindah dan laporan umur." 2013.

Halim, Abdul, dan Muhammad Syam Kusufi. 2012. Akuntansi Sektor Publik: Akuntansi Keuangan. 4ed. Salemba Empat.

Harun. 2002. "Obstacles to public sector accounting reform in Indonesia." Bulletin of Indonesian Economic Studies $43 \quad$ (3): 365-76. https://doi.org/10.1080/00074910701727613.

Helmy, Ella. 2012. "Rancang bangun sistem informasi pengelolaan keuangan daerah." Universitas Diponegoro.

Hoesada, J. 2014. "Komite standar akuntansi pemerintah (KSAP).” KSAP. 2014.

Ismadani. 2016. "PNPM bukan pendamping desa.” Kompasiana. 2016.

Jensen, Michael C., dan Cifford W. Smith. 1984. The modern theory of corporate finance. 2ed. McGraw-Hill.

Mulyadi. 2001. Sistem akuntansi. 3ed. Salemba Empat.

Papuas, Alfrianus. 2012. "Rancang bangun sistem informasi pendapatan asli daerah pada Dinas Pendapatan Daerah Kabupaten Sangihe.” Universitas Diponegoro.

Ratih, Asri Eka. 2012. "Pengaruh pemahaman sistem akuntansi keuangan daerah, 
penatausahaan keuangan daerah dan pengelolaan barang milik daerah terhadap kinerja SKPD pada Pemerintahan Provinsi Kepulauan Riau." Universitas Maritim Raja Ali Haji.

Risadi, Aris Ahmad. 2015. "Undang-undang desa: Harapan baru masyarakat desa." Kompasiana. 2015.

Rusli, Budiman. 2004. "Pelayanan publik di era reformasi.” Pikiran Rakyat, 2004.

Rusmayanti, Atik, Bambang Eka Putra, dan Sukadi. 2008. "Sistem informasi pengelolaan keuangan pada Desa Ngadirejan.” Jurnal Speed 6 (2): 35-39.

Sadjiarto, Arja. 2000. "Akuntabilitas dan pengukuran kinerja pemerintahan.” Jurnal Akuntansi dan Keuangan 2 (2): 138-50. https://doi.org/10.9744/jak.2.2.pp. 138-150.

Sarwoko, Endi. 2011. "Kajian empiris entrepreneur intention mahasiswa." Jurnal Ekonomi Bisnis 16 (2): 1261-35.

Sidik, Machfud. 2002. "Optimalisasi pajak daerah dan restribusi daerah dalam rangka meningkatkan kemampuan keuangan daerah." Orasi Ilmiah STIA LAN Bandung. 2002.

Subroto, Agus. 2009. "Akuntabilitas pengelolaan dana desa (studi kasus pengelolaan alokasi dana desa di desa-desa dalam wilayah Kecamatan Tlogomulyo Kabupaten Temanggung tahun 2008)."

Sudana, A.A.K.O. 2007. "Rancang bangun sistem informasi akuntansi pada perusahaan layanan jasaboga pesawat udara.” Jurnal Teknologi Elektro 6 (3): $1-7$.

Susetiawan. 2009. "Pembangunan dan kesejahteraan masyarakat sebuah ketidakberdayaan para pihak melawan konstruksi neoliberalisme." Pusat Studi Pedesaan dan Kawasan (PSPK) Universitas Gadjah Mada. Yogyakarta.

Tanjung, Abdul Hafiz. 2000. Akuntansi, Transparansi dan Akuntabilitas Keuangan Publik. Yogyakarta: BPFE UGM.

Utomo, T.W, dan A. Wahyudi. 2008. "Penataan kewenangan (urusan) pemerintah desa dan pengembangan standar pelayanan minimal (SPM)." Jurnal Borneo Administrasi 4 (2): 1-16.

Wiyanto, Siko Dian Sigit. 2014. “Agar dana desa terkawal.” Kementrian Keuangan. 2014.

Wrightstone, J. Wayne. 1956. Evaluation in modern education. American Book Co.

Yahya, Idhar. 2006. “Akuntabilitas dan Transparansi Pengelolaan Keuangan Daerah.” Jurnal Sistem Teknik Industri 7 (4): 27-29.

Yansen. 2014. Revolusi dari desa (saatnya dalam pembangunan percaya epenuhnya 
kepada rakyat). Jakarta: Elex Media Komputindo.

Yuliana, Muammar. 2013. "Desa kini dan masa depan dalam sudut pandang sisi dilematis UU Desa." Academia. 2013.

Yuliani, Safrida, Nadirsyah, dan Usman Bakar. 2010. "Pengaruh Pemahaman Akuntansi, Pemanfaatan Sistem Informasi Akuntansi Keuangan Daerah dan Peran Internal Audit Terhadap Kualitas Laporan Keuangan Pemerintah Daerah (Studi pada Pemerintah Kota Banda Aceh).” Jurnal Telaah \& Riset Akuntansi 3 (2): 206-20. 


\section{LAMPIRAN}

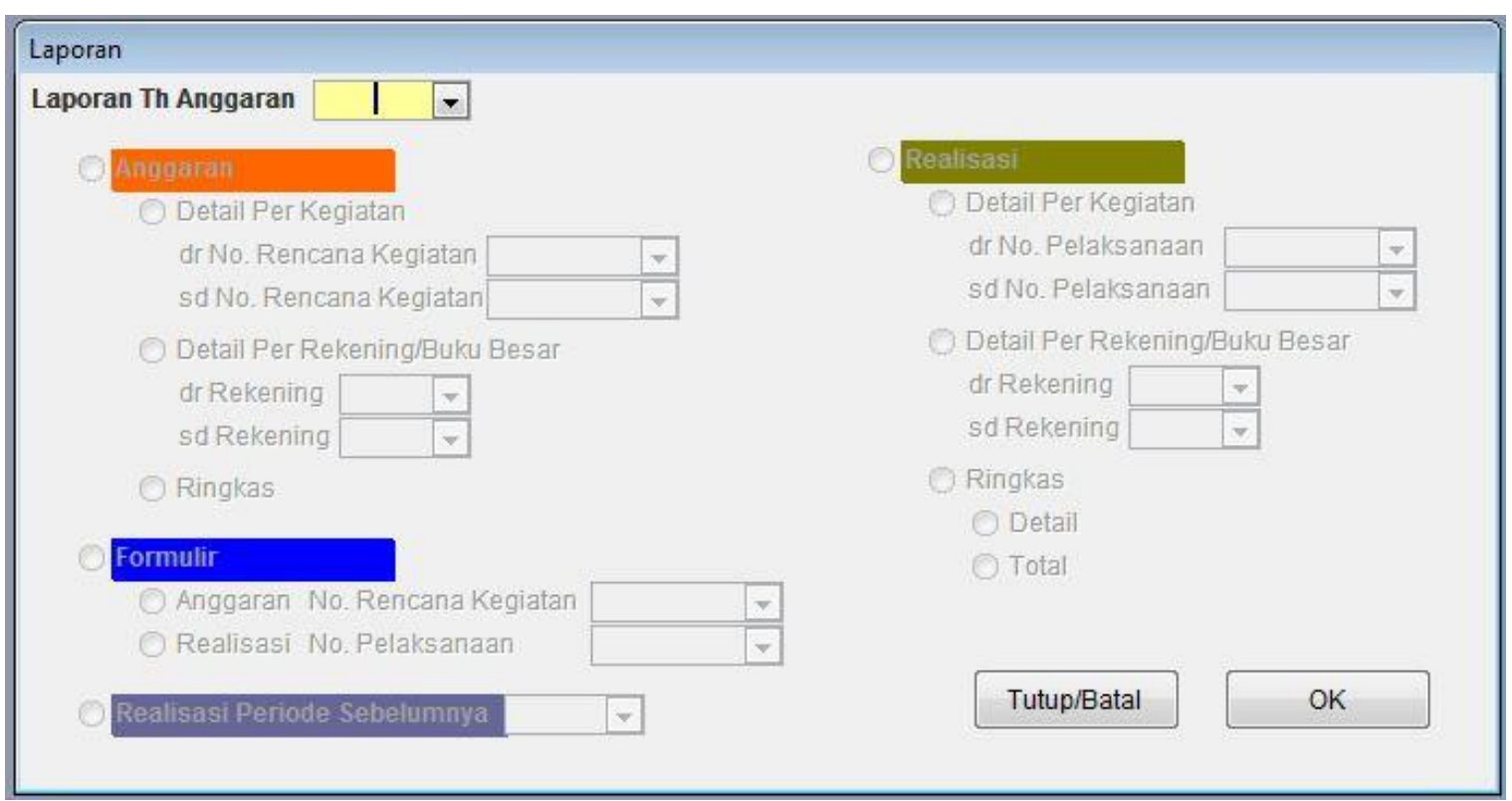

Gambar 1

Tampilan Layar Program Dana Desa 
